\title{
Determination of cGMP levels in rodent tissues following oral dosing of a soluble guanylate cyclase stimulator
}

Nisha Perez ${ }^{*}$, Christopher Graul, Peter Germano, Erik Solberg, Samuel Rivers, Robert Solinga, Joel Moore, Gerhard Hannig, Ada Silos-Santiago, Robert Busby, Daniel Zimmer

From 6th International Conference on cGMP: Generators, Effectors and Therapeutic Implications Erfurt, Germany. 28-30 June 2013

\section{Background}

In the vasculature, nitric oxide (NO) binds and activates smooth muscle soluble guanylate cyclase (sGC), leading to increased intracellular cGMP, which triggers smooth muscle relaxation and vasodilation. sGC stimulators are a class of small molecule allosteric modulators, which stimulate
cGMP production independently of NO but also act in synergy with NO. Evidence to date suggests that sGC stimulators may be balanced vasodilators, meaning that they elicit vasorelaxation in both the arterial and venous vasculature; however, there have been conflicting reports $[1,2]$. Our approach to developing a better understanding of the

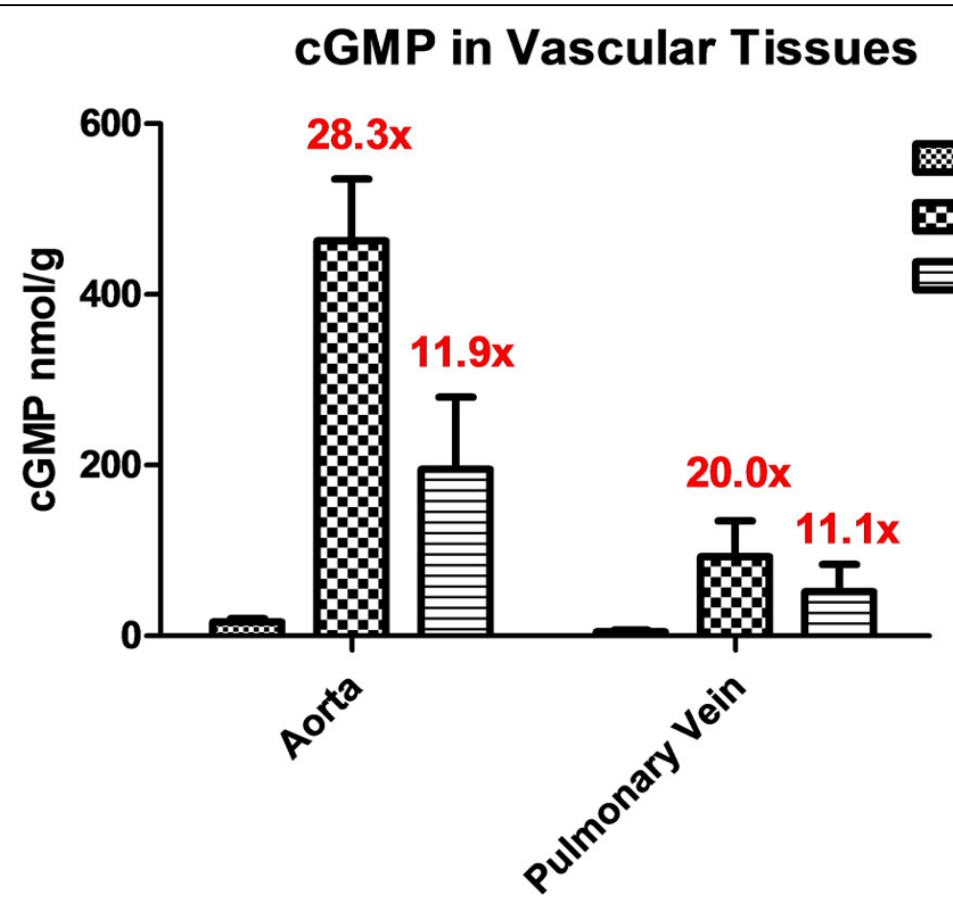

Figure 1 cGMP in vascular tissues

\footnotetext{
* Correspondence: nperez@ironwoodpharma.com

Ironwood Pharmaceuticals, Cambridge, MA 02142, USA
}

(c) 2013 Perez et al; licensee BioMed Central Ltd. This is an Open Access article distributed under the terms of the Creative Commons B. Wed Central Attribution License (http://creativecommons.org/licenses/by/2.0), which permits unrestricted use, distribution, and reproduction in 
arterio/venoselectivity of sGC stimulators was to measure cGMP concentrations in arteries, veins, plasma, and other tissues of rats orally administered with one of our sGC stimulators (MM-46446 or MM-46805) at a pharmacologically active dose. Results were treated with either vehicle or an sGC stimulator and cyclic GMP levels were measured utilizing an extraction method paired with a sensitive LC/MS-MS detection method (LLOQ $=0.3 \mathrm{nmol})$. This cGMP quantitation method is linear from $0.3-2,890$ nmol with no need for either dilutions or derivatizations, unlike current ELISA based methods that are linear from $0.2-3 \mathrm{nmol}$ and require acetylation plus sample dilutions. Using this cGMP detection method, we were able to determine that basal cGMP levels appear higher in the aorta when compared to the pulmonary vein, $16.4 \mathrm{nmol} / \mathrm{g}$ versus $4.64 \mathrm{nmol} / \mathrm{g}$, respectively. Upon treatment with either of the two sGC stimulators, aorta cGMP levels increased 28.3 and 11.9 -fold, respectively, and pulmonary vein cGMP levels increased 20.0 and 11.1-fold, respectively (Figure 1).

\section{Conclusion}

The current study shows that our sGC stimulators are able to increase cGMP levels in both the rat aorta and pulmonary vein and indicates the potential for sGC stimulators to act as balanced vasodilators.

Published: 29 August 2013

\section{References}

1. Boerrigter G, Costello-Boerrigter LC, Cataliotti A, Tsuruda T, Harty GJ,

Lapp H, Stasch JP, Burnett JC Jr: Cardiorenal and humoral properties of a novel direct soluble guanylate cyclase stimulator BAY 41-2272 in experimental congestive heart failure. Circulation 2003, 107:686-9.

2. Mitrovic V, Swidnicki B, Ghofrani A, Mück W, Kirschbaum N, Mittendorf J, Stasch JP, Wensing G, Reiner Frey R, Lentini S: Acute hemodynamic response to single oral doses of BAY $60-4552$, a soluble guanylate cyclase stimulator, in patients with biventricular heart failure. $B M C$ Pharmacology 2009, 9(Suppl 1):P51.

doi:10.1186/2050-6511-14-S1-P54

Cite this article as: Perez et al:: Determination of cGMP levels in rodent tissues following oral dosing of a soluble guanylate cyclase stimulator. BMC Pharmacology and Toxicology 2013 14(Suppl 1):P54.

\section{Submit your next manuscript to BioMed Central} and take full advantage of:

- Convenient online submission

- Thorough peer review

- No space constraints or color figure charges

- Immediate publication on acceptance

- Inclusion in PubMed, CAS, Scopus and Google Scholar

- Research which is freely available for redistribution

Submit your manuscript at www.biomedcentral.com/submit 